University of Nebraska - Lincoln

DigitalCommons@University of Nebraska - Lincoln

USDA National Wildlife Research Center - Staff Publications
U.S. Department of Agriculture: Animal and Plant Health Inspection Service

$2-16-2020$

\title{
Economic estimates of invasive wild pig damage to crops in 12 US states
}

Sophie McKee

USDA/APHIS/WS National Wildlife Research Center \& Colorado State University, Sophie.McKee@colostate.edu

Aaron Anderson

USDA/APHIS/WS National Wildlife Research Center

Keith Carlisle

USDA/APHIS/WS National Wildlife Research Center \& Colorado State University

Stephanie A. Shwiff

USDA/APHIS/WS National Wildlife Research Center

Follow this and additional works at: https://digitalcommons.unl.edu/icwdm_usdanwrc

Part of the Natural Resources and Conservation Commons, Natural Resources Management and Policy Commons, Other Environmental Sciences Commons, Other Veterinary Medicine Commons, Population Biology Commons, Terrestrial and Aquatic Ecology Commons, Veterinary Infectious Diseases Commons, Veterinary Microbiology and Immunobiology Commons, Veterinary Preventive Medicine, Epidemiology, and Public Health Commons, and the Zoology Commons

McKee, Sophie; Anderson, Aaron; Carlisle, Keith; and Shwiff, Stephanie A., "Economic estimates of invasive wild pig damage to crops in 12 US states" (2020). USDA National Wildlife Research Center - Staff Publications. 2312.

https://digitalcommons.unl.edu/icwdm_usdanwrc/2312

This Article is brought to you for free and open access by the U.S. Department of Agriculture: Animal and Plant Health Inspection Service at DigitalCommons@University of Nebraska - Lincoln. It has been accepted for inclusion in USDA National Wildlife Research Center - Staff Publications by an authorized administrator of DigitalCommons@University of Nebraska - Lincoln. 


\title{
Economic estimates of invasive wild pig damage to crops in 12 US states
}

\author{
Sophie McKee ${ }^{\mathrm{a}, \mathrm{b}, *}$, Aaron Anderson ${ }^{\mathrm{a}}$, Keith Carlisle ${ }^{\mathrm{a}, \mathrm{b}}$, Stephanie A. Shwiff ${ }^{\mathrm{a}}$ \\ ${ }^{a}$ USDA/APHIS/WS National Wildlife Research Center, 4101 Laporte Avenue Fort Collins, Colorado, 80521, USA \\ ${ }^{\mathrm{b}}$ Colorado State University, USA
}

\section{A R T I C L E I N F O}

\section{Keywords:}

Feral swine

Invasive species

Crop damage

Survey

Control methods

\begin{abstract}
A B S T R A C T
We report the results of a survey on invasive wild pig (Sus scrofa L.) damage and control in 12 US states (Alabama, Arkansas, California, Florida, Georgia, Louisiana, Mississippi, Missouri, North Carolina, Oklahoma, South Carolina, and Texas). The crops chosen for this study represent the "second tier" in terms of economic importance after the six crops that were the subject of Anderson et al. (2016). The survey was distributed by the USDA National Agricultural Statistical Service (NASS) in the summer of 2019 to a sample of producers in each of the states (except California) of the following six crops: hay, pecans (Carya illinoinensis (Wangenh.) K.Koch), melons (cantaloupe (Cucumis melo L. var. cantalupensis), honeydew (Cucumis melo L. (Inodorus Group)), and watermelon (Citrullus Schrad.), sugarcane (Saccharum officinarum L.), sweet potatoes (Ipomoea batatas (L.) Lam.), and cotton (Gossypium L.). In California, where there the crops of economic importance differed from the other states in the study, damages were calculated for producers of hay, almonds (Prunus dulcis (Mill.) D.A. Webb), grapes (Vitis vinifera L.), sod, carrots (Daucus L.), lettuce (Lactuca L.), and strawberries (Fragaria L.). In total, 7438 respondents completed the questionnaire. Findings indicate that damage can be substantial. The highest yield loss estimates occurred for hay in Texas. Control efforts were common, but no control method was rated by the majority of producers as very effective. Extrapolating crop damage estimates to the state-level in 12 states with reportable damage yielded an estimated crop loss of \$272 million/yr. Though large, this number likely represents only a small fraction of the total damage by wild pigs in these states because it only includes crop damage to six crops. We hope findings from this survey will help guide control efforts and research, as well as serve as a benchmark against which the effectiveness of future control efforts can be measured.
\end{abstract}

\section{Introduction}

Wild pigs (Sus scrofa L.), also known as wild boar, wild/feral swine, wild/feral hogs, and feral pigs (Keiter et al., 2016), are a non-native, invasive species in the U.S. that is responsible for a wide range of negative impacts, including damage to crops and livestock (Harper et al., 2016). The most widely cited aggregate estimate of wild pig damages in the U.S. comes from a 2007 study that conservatively estimates annual crop damages and control costs at $\$ 1.5$ billion (Pimentel, 2007). The author based the estimate on a population of 5 million wild pigs in the U.S. and $\$ 300^{1}$ in crop damages and control costs per swine (Pimentel, 2007). In the decade after the study was published, the geographic area of wild pig distribution increased by more than 25 percent (Corn and Jordan, 2017) despite substantial investments in control (Pepin et al., 2019), and evidence suggests that the species' population density continued to grow in many areas where populations have long been established (see Fig. 1 from Lewis et al. (2019) below).

Crops are seen as a contributing factor to the expansion of the wild pig population (Brook and van Beest, 2014; McClure et al., 2015; Lewis et al., 2017; Snow et al., 2017). Total annual damages and control costs in the U.S. may therefore be much higher than $\$ 1.5$ billion, and the development of a more accurate estimate of total costs and damage has taken on increased urgency with the growth and spread of wild pig populations. To that end, recent efforts have been made to produce more rigorous estimates of wild pig impacts at aggregated levels. In a survey study focused on six high value crops (corn (Zea mays L.), soybeans

\footnotetext{
* Corresponding author. USDA/APHIS/WS National Wildlife Research Center, 4101 Laporte Avenue Fort Collins, Colorado, 80521, USA.

E-mail address: Sophie.McKee@colostate.edu (S. McKee).

${ }^{1}$ Pimentel (2007) provides little information to explain how he arrived at $\$ 300$ per pig. As a result, it is not possible to build off of, or refine, the figure as our understanding of the scope and magnitude of wild pig-related costs and damages increases.
} 
(a) 1982

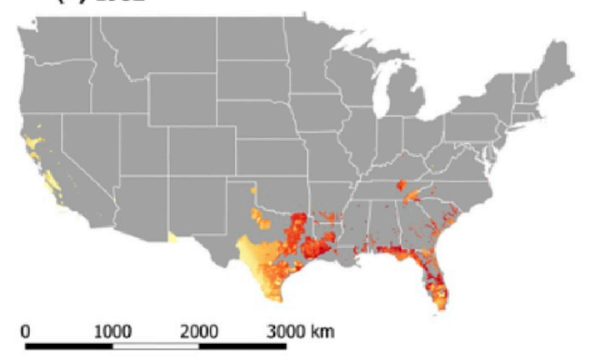

(c) 2004

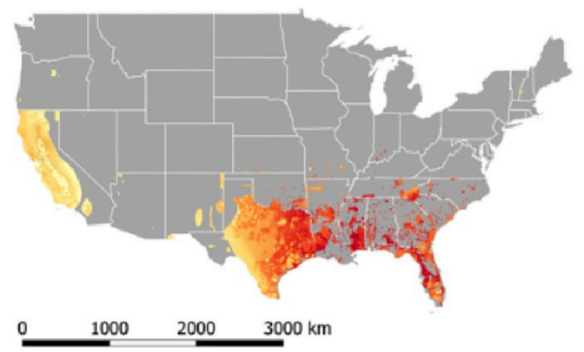

(e) 2013

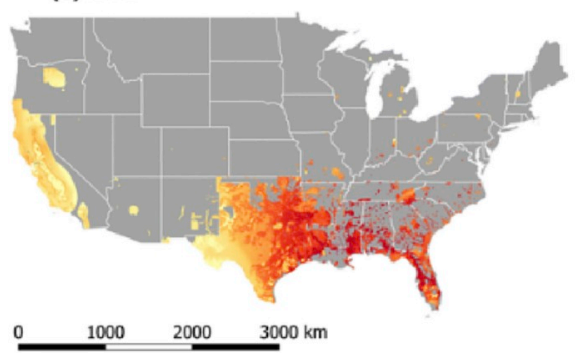

(b) 1988

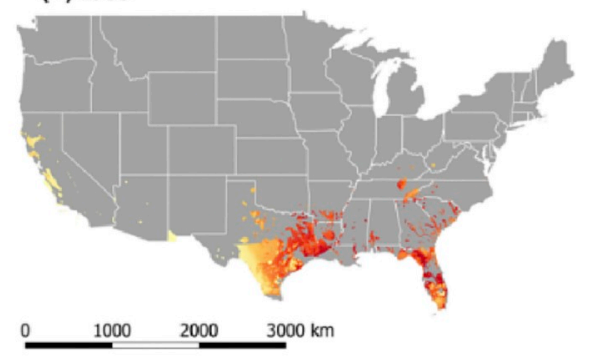

(d) 2010

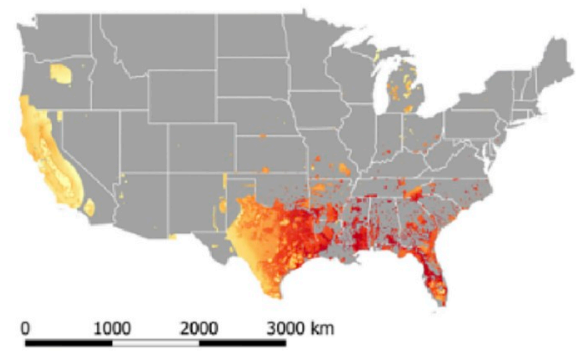

(f) 2016

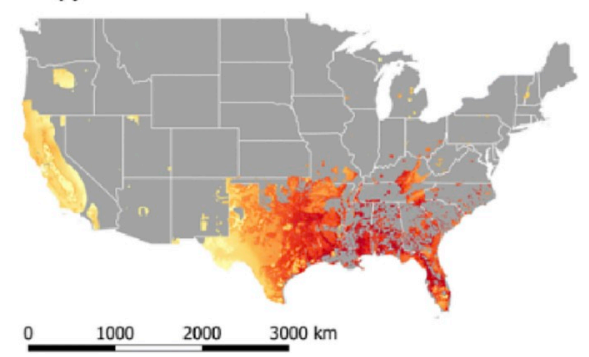

Fig. 1. Predicted potential population density of wild pigs across the United States for 1982 (a), 1988 (b), 2004 (c), 2010 (d), 2013 (e), and 2016 (f). from Lewis et al. (2019) Predicted population density ranges across values of low (yellow: $0-2$ animals $/ \mathrm{km}^{2}$ ), medium (orange: $3-5$ animals $/ \mathrm{km}^{2}$ ), and high $(\mathrm{red}$ : 6-8 animals $/ \mathrm{km}^{2}$ ). 
(Glycine max (L.) Merr), wheat (Triticum L.), rice (Oryza L.), peanuts (Arachis L.), and sorghum (Sorghum Moench)) in 11 states (Alabama, Arkansas, California, ${ }^{2}$ Florida, Georgia, Louisiana, Mississippi, Missouri, North Carolina, South Carolina, and Texas), Anderson et al. (2016) found an estimated $\$ 190$ million in crop production was lost in 2014. In a subsequent survey study focused on the same 11 states plus Oklahoma and Tennessee, Anderson et al. (2019) found that estimated damages from wild pigs to livestock on account of predation and disease were $\$ 40$ million in 2016.

For the present study, a survey was administered by the USDA National Agricultural Statistics Service (NASS) in 2019 to producers of targeted crops in 12 states to determine costs and damages associated with wild pigs. The 12 states are the same states that were the focus of Anderson et al. (2016), with the addition of Oklahoma. The crops chosen for this study represent the "second tier" in terms of economic importance after the six crops that were the subject of Anderson et al. (2016). The crops and states were selected through a subjective evaluation of economic importance, vulnerability of wild pigs, and political considerations. In each of the states except for California, damage costs were calculated for producers of the following six crop categories: hay, pecans (Carya illinoinensis (Wangenh.) K.Koch), melons (cantaloupe (Cucumis melo L. var. cantalupensis), honeydew (Cucumis melo L. (Inodorus Group)), and watermelon (Citrullus Schrad.), sugarcane (Saccharum officinarum L.), sweet potatoes (Ipomoea batatas (L.) Lam.), and cotton (Gossypium L.). In California, where there the crops of economic importance differed from the other states in the study, damages were calculated for producers of hay, almonds (Prunus dulcis (Mill.) D.A. Webb), grapes (Vitis vinifera L.), sod, carrots (Daucus L.), lettuce (Lactuca L.), and strawberries (Fragaria L.).

The survey was designed to simultaneously capture information related to wild pig presence, crop damage, livestock losses, control methods, live sales, and hunting, but the focus of the present analysis is on wild pig presence, crop damage, and control efforts. We proceed with a discussion of the survey distribution, NASS rules related to disclosure of information, and the survey instrument. Results are then presented, followed by a discussion of the implications of the findings.

\section{Methods}

A self-administered survey questionnaire was mailed in July 2019 to 15,067 producers in the 12 states, along with a stamped return envelope. Additionally, representatives of NASS made up to ten follow-up calls to non-respondents in an effort to administer the survey by phone. In total, 7,438 respondents completed the questionnaire, for a response rate of $49.3 \%$.

To calculate estimates of wild pig impacts at the state level, weights provided by NASS were used to account for state-wide production of each crop. Additionally, individual-level responses were weighted to account for non-response by other producers in the sample, rendering estimates of wild pig damages representative at the state level. In cases where either a single producer made up a large portion of responses to a specific question or only a few individuals responded to the questions, NASS rules prevent disclosure of values to in order to protect the private information of producers. At the state level, these disclosure requirements are largely unrestrictive in terms of limiting presentable results. Some survey responses at the more disaggregated level of crops within states were not as immune to disclosure concerns and were consequently suppressed. For this reason, summary statistics at the state-crop level cannot be reported in some cases, because of the low response rate results in some categories being dominated by a single producer.

\footnotetext{
${ }^{2}$ Estimated damages for California were not included in the publication and were not taken into account in calculating total estimated damages due to privacy concerns.
}

Our focus here is on four types of information collected by the survey. The first is the presence of wild pigs. Wild pig presence provides a general indication of the economic threat they pose in the area, either through direct damage or the risk of disease transmission. We asked two general questions regarding wild pig presence in the producer's county and on their operation (Fig. 2).

General information on damage to crops and property was then solicited by questions listed in Figs. 3 and 4. Wild pigs damage pasture and agricultural crops by consumption, rooting, digging, and trampling (Seward et al., 2004). Producers could choose to respond for up to three of their highest valued crops harvested on their operation in 2018. Each producer was asked if there were any crops, including trees/orchards, hay, and sod, harvested on their operation in 2018. If so, they could report up to three crops. For each of these crops, they were asked if, to the best of their knowledge, wild pigs had been present on any field of the crop, if the presence of wild pigs made the crop more costly to harvest, and if there was crop damage from wild pigs on acres harvested in 2018. Sections on livestock production and damage, property damage, wild pig control methods, and hunting followed.

The structure of the questions related to crop damage enabled us to capture information from producers that experienced no crop damage from wild pigs so that we could use the survey results to extrapolate to the state-level. The questions also go beyond simply soliciting a percentage yield loss response. Instead, producers were asked how many of the acres of each crop were damaged by wild pigs, as well as actual yield with the damage and expected yield without the damage on those acres. Self-reporting wildlife damages the crops is common and has been shown to be accurate (Conover, 2002; Johnson-Nistler et al., 2005; Tzilkowski et al., 2002; Wywialowski, 1994).

To calculate wild pig damage to crops, we compared actual yield reported by each producer to the expected yield reported if no wild pig damage had occurred. Specifically, each producer reported total acres harvested for each of up to three crops, as well as average yield per acre, giving total yield. For crop $j$ on producer $i$ 's operation, this is:

$$
\text { Yield }_{i j}=\left(\text { acres harvested }_{i j}\right)\left(\text { avg. yield per } \text { acre }_{i j}\right) \text {. }
$$

If some acres were reported damaged by wild pigs, producers reported: (i) the number of acres damaged, (ii) average yield per acre on damaged acres, and (iii) expected yield per acre if these acres had not been damaged. Hypothetical yield losses for each producer's crops are then calculated as:

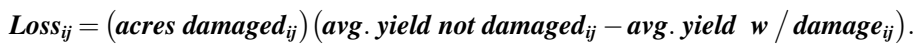

Since actual yield on damaged acres was included in the original calculation of total yield in (1), hypothetical yield without wild pig damage is the sum of (1) and (2). Hypothetical yield loss due to wild pig damage as a percentage of total (hypothetical) yield is then:

Percent Loss $_{i j}=100 \times \frac{\text { Loss }_{i j}}{\text { Yield }_{i j}+\text { Loss }_{i j}}$.

Equation (3) gives the portion of yield lost to wild pig damage at the producer-crop level. To calculate the portion of yield lost for each crop within each state, we summed yield and hypothetical loss across all producers of each crop in each state as in (1) and (2), and used these to calculate the portion of each crop's yield lost to wild pigs across the state. Along with the producer level responses needed to calculate (3), each producer was given a calculated weight based on a non-response adjustment and Multivariate Probability Proportional to Size (MPPS) weight, as in Kott et al. (1998). These producer-level weights were 
4. During the last three years, have wild pigs been present in the county reported in item 3? For purposes of this study, "wild pig" refers to any pig or hog that is roaming free and does not have an owner. Other names for "wild pig" include feral hog, wild boar, feral pig, and feral swine.

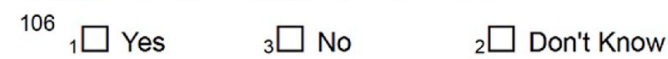

\section{During the last three years, have wild pigs been present on your operation?}

107

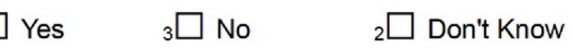

Fig. 2. Wild pig presence questions from the survey instrument.

adjusted to account for non-response to specific questions and used in the calculations that follow, specifically by weighting each producer's yields and losses in (1) and (2) by their unique weight in order to obtain a representative value at the state level.

To estimate the dollar value of production lost to wild pig damage for the selected crops at the state level, we assumed that the weights used to account for non-response and farm size are also applicable to wild pig damage. In other words, we assumed that the damage experienced by the weighted sample of observed producers is representative of all producers of the same crop in their state. Under this assumption, estimated production value lost to wild pigs is the percentage loss by state and crop from Table 1. For crop $j$ in state $s$, the calculation of percentage loss analogous to (3) is:

Percent Loss $_{j s}=100 \times \frac{\text { Loss }_{j s}}{\text { Yield }_{j s}+\operatorname{Loss}_{j s}}$.

The dollar value of lost production in dollars is then

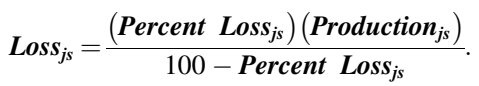

Current production value for the selected crops and states Production $_{j s}$ were obtained from NASS Quick Stats for the year2017 (the most recent available census year at the time of writing).

Additional questions solicited information on wild pig control efforts (Fig. 5). Producers were asked about the use of each method, the cost of each method, and their perceptions about the effectiveness of each method.

\section{Results}

\subsection{Wild pig presence in county and on operation}

Figs. 6 and 7 present the percentage of respondents by state who reported wild pig presence in their county and on their operation during the previous three years. Complete results are shown in Table A.1. in the Appendix. 59\% of the producers of the targeted commodities in these states reported being aware of wild pig presence in their county, and $38 \%$ of the producers reported being aware of wild pig presence on their operation during this period. The highest proportion of producers reporting wild pig presence on their property is in Texas at $78 \%$, followed by Oklahoma at $67 \%$.

\subsection{Wild pig damage}

Fig. 8 shows responses by state to the following questions: (i) presence of wild pigs on a respondent's crops, (ii) additional cost to harvest crops on account of wild pigs, (iii) damage from wild pigs on crops harvested, and (iv) damage to any of the property items listed in Fig. 4 from wild pigs in 2018. Across all 12 states, one-third of producers reported wild pig presence on their land, 29\% reported crop damage, $23 \%$ reported that wild pigs make it more costly for them to harvest their crop, and 33\% reported property damage from wild pigs. Among individual states, respondents from Texas and Oklahoma were most likely to indicate the presence of wild pigs on their land $(70 \%$, and $58 \%$ respectively), that wild pigs make it more costly for them to harvest their crop ( $55 \%$ and $44 \%$ ), damage by wild pigs to crops (59\% and $49 \%$ ), and damage by wild pigs to property ( $73 \%$ and $65 \%)$. Complete results are presented in Table A-2 in the Appendix.

We note that some observations of crop-level data were unusable (e. g. a producer reported wild pig damage to a crop but no acres were damaged, or a producer reported on crops other than those listed in Table 1). Table A-3 in the Appendix reports the number of useable observations for calculating percentage yield loss at the state-crop level. Hay, tree nuts, and cotton provide the largest sample sizes.

The results of the yield loss calculations for the crops of interest are presented in Table 1. Mean reported damage to hay was markedly higher in Texas (6.59\%), Georgia (6.51\%), and Louisiana (6.03\%), while reported pecan damage was substantially higher in Texas (13.46\%) and Florida (12.56\%).

Estimates of production value lost to wild pigs, as calculated in (5), are presented in Table 2. For the selected crops and states which are reportable, an estimated $\$ 272$ million in crop production was lost to wild pig damage in 2018. A comparison across crops shows that hay has the highest value of reported crop losses $(\$ 162,626)$. However, given the total value of production in the 12 states of the different crops, tree nut production suffers much larger monetary losses as a percentage of total production value ( $13.46 \%$ in Texas, $12.56 \%$ in Florida). The results also indicate that Texas suffers substantially larger monetary losses than other states $(\$ 115,978)$.

\subsection{Wild pig control}

Fig. 9 depicts for each state the percentage of producers who reported making attempts to control wild pigs, both in general and by specific control method. Full results are presented in Table A-4 in the appendix. More than one third (34\%) mentioned at least one control method being used on their property in 2018. Across all twelve states, the most widely used control method was shooting wild pigs on sight (26\%), followed by hunting without dogs and trapping and removing (both at 16\%). The least widely used (1\%) was repellents. The state with the highest rate of control was Texas at $75 \%$. Producers were also asked if they would be likely to use a reasonably-priced wild pig toxicant on their operation if it were available and if it caused minimal suffering, posed no risk to human health, and caused little harm to other wildlife. The proportion of producers who answered in the affirmative is presented in the last column of Table A-4. 55\% replied positively across the 12 states. The highest proportion of positive responses can be found in Texas at $68 \%$ and the lowest in California at $35 \%$.

Producers were also asked to rate the effectiveness of a control method if they used it. Results are presented in Table 3. Hunting with dogs is the method most often rated as very effective.

${ }^{3}$ Or the closest year when 2017 data wasn't available. 


\begin{tabular}{|c|c|c|c|}
\hline & \\
\hline & $\begin{array}{l}\text { Crop With Highest } \\
\text { Value of Production }\end{array}$ & $\begin{array}{l}\text { Crop With Second } \\
\text { Highest Value of } \\
\text { Production }\end{array}$ & $\begin{array}{l}\text { Crop With Third } \\
\text { Highest Value of } \\
\text { Production }\end{array}$ \\
\hline $\begin{array}{l}\text { a. In } 2018 \text {, which crop(s) harvested on your } \\
\text { operation produced the highest value of } \\
\text { production? Report for up to three crops. }\end{array}$ & 109 & 110 & 1111 \\
\hline $\begin{array}{l}\text { b. How many total acres of this crop were } \\
\text { planted? }\end{array}$ & 112 & 113 & 114 \\
\hline $\begin{array}{l}\text { c. How many total acres of this crop were } \\
\text { harvested? }\end{array}$ & 115 & 116 & 117 \\
\hline $\begin{array}{l}\text { (i) What was the average yield per acre of } \\
\text { this crop? }\end{array}$ & 118 & 119 & 120 \\
\hline $\begin{array}{l}\text { (ii) What was the unit for the yield } \\
\text { reported in row } \mathrm{c}(\mathrm{i}) \text { above? }\end{array}$ & 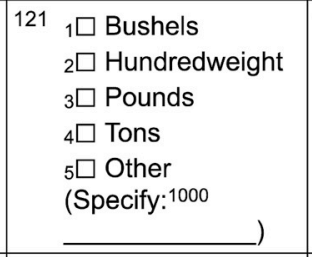 & $\begin{array}{|ll|}122 & 1 \square \text { Bushels } \\
& 2 \square \text { Hundredweight } \\
& 3 \square \text { Pounds } \\
& 4 \square \text { Tons } \\
& 5 \text { Other } \\
& \text { (Specify: }: 1001 \\
\end{array}$ & $\begin{array}{ll}123 & 1 \square \text { Bushels } \\
& 2 \square \text { Hundredweight } \\
& 3 \square \text { Pounds } \\
& 4 \square \text { Tons } \\
& 5 \text { Other } \\
& (\text { Specify: } 1002 \\
\end{array}$ \\
\hline $\begin{array}{l}\text { (iii) What was the average price received, } \\
\text { or expected to be received, for this } \\
\text { crop harvested in } 2018 \text { ? (If this crop } \\
\text { was or will be used on the operation } \\
\text { instead of being sold, please give your } \\
\text { best estimate of the crop's value). }\end{array}$ & $\ldots$ _/unit & __/unit & $\ldots$ /unit \\
\hline (iv) Was this crop certified as organic? & $\begin{array}{cc}127 & 1 \square \text { Yes } \\
& 3 \square \text { No } \\
\end{array}$ & $\begin{array}{ll}128 & 1 \square \text { Yes } \\
& 3 \square \text { No }\end{array}$ & $\begin{array}{ll}129 & 1 \square \text { Yes } \\
& 3 \square \text { No }\end{array}$ \\
\hline $\begin{array}{l}\text { d. To the best of your knowledge were wild } \\
\text { pigs present on any field of this crop? }\end{array}$ & \begin{tabular}{|l|}
130 \\
$1 \square$ Yes - Continue \\
$3 \square$ No - Go to Item 2e \\
${ }_{2} \square$ Don't Know - Go to Item 2e
\end{tabular} & $\begin{array}{l}131 \\
1 \square \text { Yes - Continue } \\
3 \square \text { No - Go to Item 2e } \\
2 \square \text { Don't Know - Go to Item 2e }\end{array}$ & $\begin{array}{l}132 \\
1 \square \text { Yes - Continue } \\
3 \square \text { No - Go to Item 2e } \\
2 \square \text { Don't Know - Go to Item 2e }\end{array}$ \\
\hline $\begin{array}{l}\text { (i) Did the presence of wild pigs make this } \\
\text { crop more costly to harvest? }\end{array}$ & $\begin{array}{l}350 \\
{ }_{1} \square \text { Yes - Continue } \\
{ }_{3} \square \text { No - Go to Item 2d.iii } \\
{ }_{2} \square \text { Don't Know - } \\
\quad \text { Go to Item 2d.iii }\end{array}$ & $\begin{array}{l}351 \\
1 \square \text { Yes - Continue } \\
3 \square \text { No - Go to Item 2d.iii } \\
\text { 2 } \square \text { Don't Know - } \\
\quad \text { Go to Item 2d.iii }\end{array}$ & $\begin{array}{l}352 \\
1 \square \text { Yes - Continue } \\
3 \square \text { No - Go to Item 2d.iii } \\
2 \square \text { Don't Know - } \\
\quad \text { Go to Item 2d.iii }\end{array}$ \\
\hline $\begin{array}{l}\text { (ii) What is your best estimate of how } \\
\text { much more costly this crop was to } \\
\text { harvest in } 2018 \text { because of the } \\
\text { presence of wild pigs (including the } \\
\text { value of your time, labor, and any } \\
\text { additional equipment that may have } \\
\text { been required)? }\end{array}$ & 353 & 354 & 355 \\
\hline (iii) Was this crop damaged by wild pigs? & \begin{tabular}{|l|}
133 \\
${ }_{1} \square$ Yes - Continue \\
${ }_{3} \square$ No - Go to Item 2e \\
${ }_{2} \square$ Don't Know - Go to Item 2e
\end{tabular} & $\begin{array}{l}134 \\
1 \square \text { Yes - Continue } \\
{ }_{3} \square \text { No - Go to Item 2e } \\
2 \square \text { Don't Know - Go to Item 2e }\end{array}$ & $\begin{array}{l}135 \\
1 \square \text { Yes - Continue } \\
3 \square \text { No - Go to Item 2e } \\
2 \square \text { Don't Know - Go to Item 2e }\end{array}$ \\
\hline $\begin{array}{l}\text { (iv) How many acres of this crop were } \\
\text { damaged by wild pigs? }\end{array}$ & 136 & 137 & 138 \\
\hline $\begin{array}{l}\text { (v) What was the average yield per acre } \\
\text { of the acres damaged by wild pigs? } \\
\text { (use the same unit used on previous } \\
\text { page) }\end{array}$ & 139 & 140 & 141 \\
\hline $\begin{array}{l}\text { (vi) If these acres had not been damaged, } \\
\text { what would have been their yield per } \\
\text { acre? (use the same unit used on } \\
\text { previous page) }\end{array}$ & 142 & 143 & 144 \\
\hline
\end{tabular}

Fig. 3. Wild pig crop damage questions from the survey instrument. 


\section{SECTION 4 - PROPERTY}

1. In 2018 , which of the following types of damage due to wild pigs occurred on your operation? If property was damaged how much did it cost, or would you estimate it would cost, to repair the damage, and how severe was the damage?

\begin{tabular}{|c|c|c|c|c|c|c|c|}
\hline \multirow[b]{2}{*}{ Damage Type } & \multirow[b]{2}{*}{ Did damage occur? } & \multirow{2}{*}{$\begin{array}{c}\text { Cost of } \\
\text { damage } \\
\text { (or estimate of } \\
\text { repair), } \\
\text { including } \\
\text { materials, } \\
\text { labor, and the } \\
\text { value of your } \\
\text { time }\end{array}$} & \multicolumn{5}{|c|}{ How much damage occurred? Check one per row } \\
\hline & & & $\begin{array}{c}\text { Mild } \\
\text { Damage }\end{array}$ & $\begin{array}{l}\text { Moderate } \\
\text { Damage }\end{array}$ & $\begin{array}{l}\text { Somewhat } \\
\text { Severe } \\
\text { Damage }\end{array}$ & $\begin{array}{l}\text { Very } \\
\text { Severe } \\
\text { Damage }\end{array}$ & Unsure \\
\hline a. Building damage & $\begin{aligned} & 206 \\
1 & \square \text { Yes } \\
& \\
& \square \\
2 & \square \text { No Don't Know }\end{aligned}$ & $\begin{array}{l}207 \\
\$\end{array}$ & ${ }_{1}^{208}$ & ${ }_{2} \square$ & ${ }_{3} \square$ & ${ }_{4} \square$ & ${ }_{5} \square$ \\
\hline b. Fencing damage & $\begin{aligned} & 209 \text { Yes } \\
& \square \square \text { No } \\
& \square \square \text { Don't Know }\end{aligned}$ & $\begin{array}{l}210 \\
\$\end{array}$ & $\begin{array}{ll}211 & \\
& \\
& \\
& \square \\
\end{array}$ & $2 \square$ & ${ }_{3} \square$ & ${ }_{4} \square$ & ${ }_{5} \square$ \\
\hline $\begin{array}{l}\text { c. Field, orchard, and/or } \\
\text { pasture damage }\end{array}$ & $\begin{array}{l}360{ }_{1} \square \text { Yes } \\
{ }_{3} \square \text { No } \\
{ }_{2} \square \text { Don't Know }\end{array}$ & $\begin{array}{l}361 \\
\$\end{array}$ & $\begin{array}{ll}362 & \\
& \\
& \\
& \end{array}$ & ${ }_{2} \square$ & ${ }_{3} \square$ & ${ }_{4} \square$ & ${ }_{5} \square$ \\
\hline $\begin{array}{l}\text { d. Crop damage that was } \\
\text { not already reported in } \\
\text { Section } 2\end{array}$ & 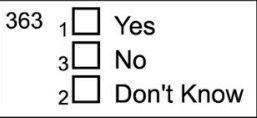 & $\begin{array}{l}364 \\
\$\end{array}$ & $\begin{array}{ll}365 & \\
& \\
& \\
& \square\end{array}$ & ${ }_{2} \square$ & ${ }_{3} \square$ & ${ }_{4} \square$ & ${ }_{5} \square$ \\
\hline $\begin{array}{l}\text { e. Livestock waterers, } \\
\text { water pumps, and/or } \\
\text { irrigation equipment damage }\end{array}$ & $\begin{array}{rl}212 & 1 \square \text { Yes } \\
& \\
& \square \text { No } \\
& \square \\
\end{array}$ & $\begin{array}{l}213 \\
\$\end{array}$ & $\begin{array}{ll}214 & \\
& \\
& \\
& \square\end{array}$ & $2 \square$ & ${ }_{3} \square$ & ${ }_{4} \square$ & ${ }_{5} \square$ \\
\hline $\begin{array}{l}\text { f. Vehicle, tractor, and/or } \\
\text { farm equipment damage }\end{array}$ & $\begin{array}{rl}215 & 1 \square \text { Yes } \\
& \\
3 & \square \text { No } \\
& \\
2 & \square \text { Don't Know }\end{array}$ & $\begin{array}{l}216 \\
\$\end{array}$ & $\begin{array}{ll}217 & \\
& \\
& \\
& \end{array}$ & ${ }_{2} \square$ & ${ }_{3} \square$ & ${ }_{4} \square$ & ${ }_{5} \square$ \\
\hline g. Road damage & $\begin{array}{l}221, \square \text { Yes } \\
{ }_{3} \square \text { No } \\
2 \square \text { Don't Know }\end{array}$ & $\begin{array}{l}222 \\
\$\end{array}$ & ${ }_{1}^{223}$ & ${ }_{2} \square$ & ${ }_{3} \square$ & ${ }_{4} \square$ & ${ }_{5} \square$ \\
\hline $\begin{array}{l}\text { h. Livestock feed, grain, and/or } \\
\text { hay damage that was not } \\
\text { already reported in Section } 3\end{array}$ & 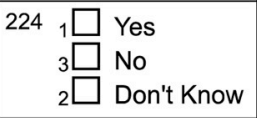 & $\begin{array}{l}225 \\
\$\end{array}$ & $\begin{array}{ll}226 & \\
& \\
& \\
& \square\end{array}$ & ${ }_{2} \square$ & ${ }_{3} \square$ & ${ }_{4} \square$ & ${ }_{5} \square$ \\
\hline i. Fecal contamination of water & $\begin{array}{rl}235 & 1 \square \text { Yes } \\
& \\
3 & \square \text { No } \\
2 & \square \text { Don't Know }\end{array}$ & $\begin{array}{l}370 \\
\$\end{array}$ & $\begin{array}{ll}236 & \\
& \\
& \\
& \square\end{array}$ & $2 \square$ & ${ }_{3} \square$ & ${ }_{4} \square$ & ${ }_{5} \square$ \\
\hline $\begin{array}{l}\text { j. Other damage to terraces, } \\
\text { stream banks, and/or ponds }\end{array}$ & 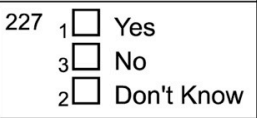 & $\begin{array}{l}371 \\
\$\end{array}$ & $\begin{array}{ll}228 & \\
& \\
& \\
& \square\end{array}$ & ${ }_{2} \square$ & ${ }_{3} \square$ & ${ }_{4} \square$ & ${ }_{5} \square$ \\
\hline $\begin{array}{l}\text { k. Loss of wildlife habitat and } \\
\text { non-crop trees }\end{array}$ & $\begin{array}{rl}229 & 1 \square \text { Yes } \\
& 3 \square \text { No } \\
& 2 \square \text { Don't Know }\end{array}$ & $\begin{array}{l}372 \\
\$\end{array}$ & ${ }_{1}^{230}$ & ${ }_{2} \square$ & ${ }_{3} \square$ & ${ }_{4} \square$ & ${ }_{5} \square$ \\
\hline I. Field topsoil erosion & 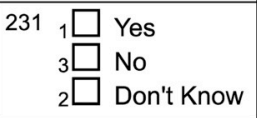 & $\begin{array}{l}373 \\
\$\end{array}$ & $\begin{array}{ll}232 & \\
& \\
& \\
& \square\end{array}$ & ${ }_{2} \square$ & ${ }_{3} \square$ & ${ }_{4} \square$ & ${ }_{5} \square$ \\
\hline $\begin{array}{l}\text { m. Fecal contamination of } \\
\text { crops that was not already } \\
\text { reported in Section } 2\end{array}$ & $\begin{array}{rl}237 & 1 \square \text { Yes } \\
& \\
& \\
& \square \\
2 & \square \text { No Don't Know }\end{array}$ & $\begin{array}{l}374 \\
\$\end{array}$ & $\begin{array}{ll}238 & \\
& \\
& \\
& \square\end{array}$ & ${ }_{2} \square$ & ${ }_{3} \square$ & ${ }_{4} \square$ & ${ }_{5} \square$ \\
\hline $\begin{array}{l}\text { n. Other damage } \\
\text { (Specify: }{ }^{1007}\end{array}$ & $\begin{array}{rl}239 & 1 \square \text { Yes } \\
& 3 \square \text { No } \\
& 2 \square \text { Don't Know }\end{array}$ & $\begin{array}{l}240 \\
\$\end{array}$ & $\begin{array}{ll}241 & \\
& \\
& \square\end{array}$ & ${ }_{2} \square$ & ${ }_{3} \square$ & ${ }_{4} \square$ & ${ }_{5} \square$ \\
\hline
\end{tabular}

Fig. 4. Wild pig control questions from the survey instrument. 
Table 1

Percent of crop lost to wild pigs (aggregated by states).

\begin{tabular}{|c|c|c|c|c|c|c|c|c|c|}
\hline State & Hay, haylage & Pecans almonds & Melons & Sugarcane & Sweet potatoes & Cotton & Grapes & Lettuce & Strawberry \\
\hline Alabama & $4.46 \%$ & $6.95 \%$ & $0.00 \%$ & NA & $5.17 \%$ & $0.89 \%$ & NA & NA & NA \\
\hline Arkansas & $4.90 \%$ & $0.93 \%$ & (D) & NA & (D) & $0.26 \%$ & NA & NA & NA \\
\hline California & $0.45 \%$ & $0.04 \%$ & NA & NA & NA & NA & $0.22 \%$ & $0.00 \%$ & $0.06 \%$ \\
\hline Florida & $2.06 \%$ & $12.56 \%$ & $1.84 \%$ & $0.90 \%$ & (D) & $3.01 \%$ & NA & NA & NA \\
\hline Georgia & $6.51 \%$ & $5.67 \%$ & $0.48 \%$ & NA & $1.64 \%$ & $2.01 \%$ & NA & NA & NA \\
\hline Louisiana & $6.03 \%$ & $2.90 \%$ & (D) & $0.35 \%$ & (D) & $0.00 \%$ & NA & NA & NA \\
\hline Mississippi & $0.91 \%$ & $0.00 \%$ & (D) & NA & $1.04 \%$ & $0.05 \%$ & NA & NA & NA \\
\hline Missouri & $2.47 \%$ & NA & $0.00 \%$ & NA & (D) & $0.00 \%$ & NA & NA & NA \\
\hline North Carolina & $0.15 \%$ & $0.00 \%$ & $0.00 \%$ & NA & $1.74 \%$ & $0.11 \%$ & NA & NA & NA \\
\hline Oklahoma & $3.08 \%$ & $3.93 \%$ & (D) & NA & (D) & $0.35 \%$ & NA & NA & NA \\
\hline South Carolina & $1.35 \%$ & $0.00 \%$ & $1.03 \%$ & (D) & $0.00 \%$ & $1.88 \%$ & NA & NA & NA \\
\hline Texas & $6.59 \%$ & $13.46 \%$ & $8.36 \%$ & $0.00 \%$ & (D) & $0.37 \%$ & NA & NA & NA \\
\hline
\end{tabular}

\section{SECTION 5 - CONTROL}

1. In 2018, which of the following control methods were used on your operation in order to reduce or prevent damage from wild pigs? If the method was used in 2018, how much did that method cost (including labor) and how effective was it?

\begin{tabular}{|c|c|c|c|c|c|c|}
\hline \multirow[b]{2}{*}{ Control Method } & \multirow[b]{2}{*}{$\begin{array}{c}\text { Used on } \\
\text { operation in } \\
2018 ?\end{array}$} & \multirow{2}{*}{$\begin{array}{c}\text { Cost in } 2018 \\
\text { (Include } \\
\text { materials, } \\
\text { labor, and the } \\
\text { value of your } \\
\text { time) } \\
\text { (Dollars) }\end{array}$} & \multicolumn{4}{|c|}{$\begin{array}{l}\text { How effective was the control method? } \\
\text { Check one per row }\end{array}$} \\
\hline & & & $\begin{array}{c}\text { Not } \\
\text { Effective }\end{array}$ & $\begin{array}{l}\text { Slightly } \\
\text { Effective }\end{array}$ & $\begin{array}{c}\text { Moderately } \\
\text { Effective }\end{array}$ & $\begin{array}{c}\text { Very } \\
\text { Effective }\end{array}$ \\
\hline a. Shooting wild pigs on sight & $\begin{array}{cc}243 & 1 \square \text { Yes } \\
& \\
& \\
& \square\end{array}$ & 244 & $\begin{array}{ll}245 & \\
& 1 \square\end{array}$ & $2 \square$ & ${ }_{3} \square$ & ${ }_{4} \square$ \\
\hline b. Hunting wild pigs with dogs & $\begin{array}{cc}246 & \\
1 & \square \text { Yes } \\
& \\
& \square \text { No }\end{array}$ & $\begin{array}{l}247 \\
\$\end{array}$ & 248 & ${ }_{2} \square$ & ${ }_{3} \square$ & ${ }_{4} \square$ \\
\hline c. Hunting wild pigs without dogs & 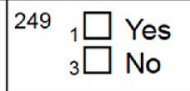 & $\begin{array}{l}250 \\
\$\end{array}$ & 251 & ${ }_{2} \square$ & ${ }_{3} \square$ & ${ }_{4} \square$ \\
\hline d. Aerial hunting & $\begin{array}{cc}252 & 1 \square \text { Yes } \\
& \\
& \\
& \square \text { No }\end{array}$ & $\begin{array}{l}253 \\
\$\end{array}$ & 254 & ${ }_{2} \square$ & ${ }_{3} \square$ & ${ }_{4} \square$ \\
\hline e. Trapping and removing wild pigs & $\begin{array}{c}255 \quad \square \text { Yes } \\
\\
3 \square \text { No }\end{array}$ & 256 & 257 & $2 \square$ & ${ }_{3} \square$ & ${ }_{4} \square$ \\
\hline f. Repellents for wild pigs & $\begin{array}{c}258 \quad \begin{array}{l}2 \\
1\end{array} \\
3 \square \text { Yes }\end{array}$ & 259 & 260 & ${ }_{2} \square$ & ${ }_{3} \square$ & ${ }_{4} \square$ \\
\hline $\begin{array}{l}\text { g. Other, excluding fencing } \\
\text { (Specify } 1008\end{array}$ & $\begin{array}{c}261 \quad \square \text { Yes } \\
{ }_{3} \square \text { No }\end{array}$ & $\begin{array}{l}262 \\
\$\end{array}$ & ${ }_{1} \square$ & ${ }_{2} \square$ & ${ }_{3} \square$ & ${ }_{4} \square$ \\
\hline
\end{tabular}

2. If a reasonably-priced wild pig poison were available that causes minimal suffering, poses no risk to human health, and causes little harm to other wildlife, would you be likely to use it on your operation to reduce or prevent damage from wild pigs?

380
$\square$ Yes
$\square$ No

3. Did you install electric fencing on your operation for the primary purpose of reducing damage by wild pigs? 264 ${ }_{1} \square$ Yes - Continue $\quad{ }_{3} \square$ No - Go to Item 4

Fig. 5. Wild pig control questions from the survey instrument. 


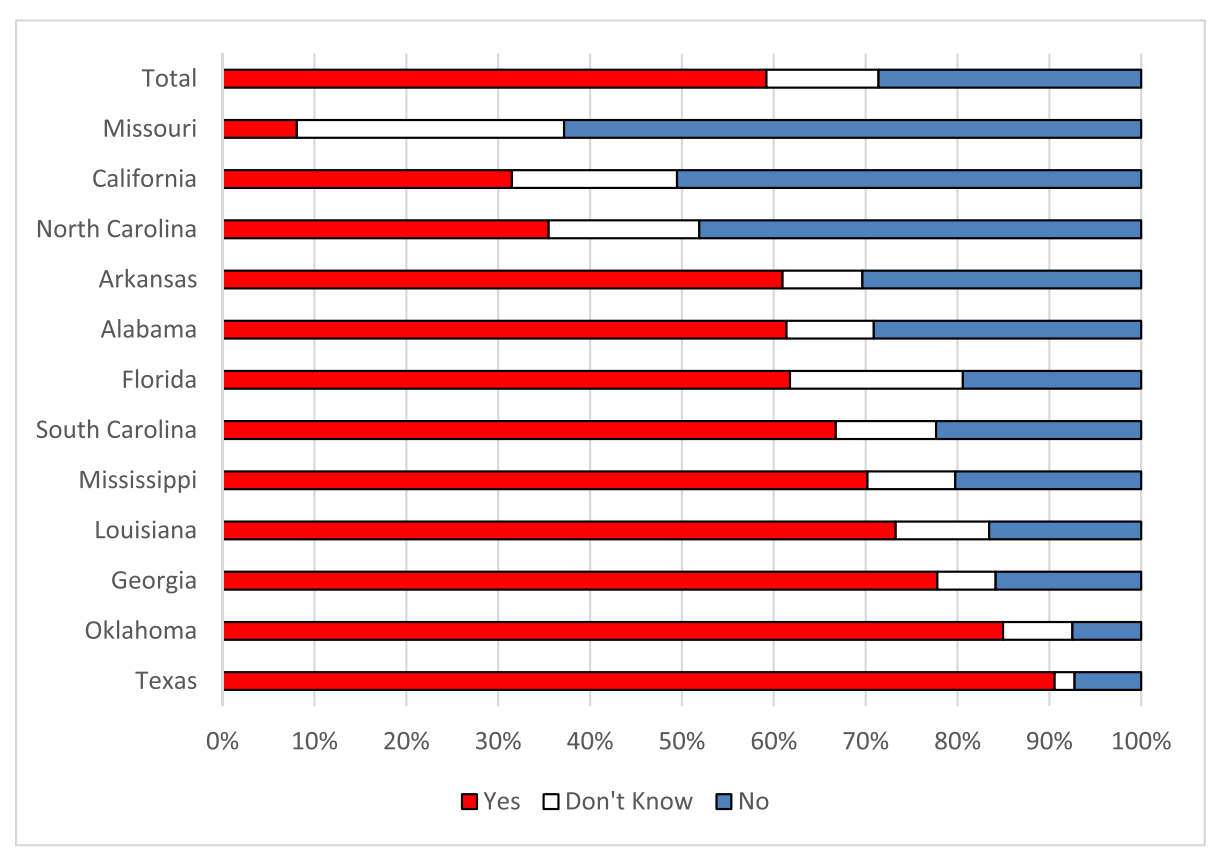

Fig. 6. Percent of landowners reporting wild pig presence in county.

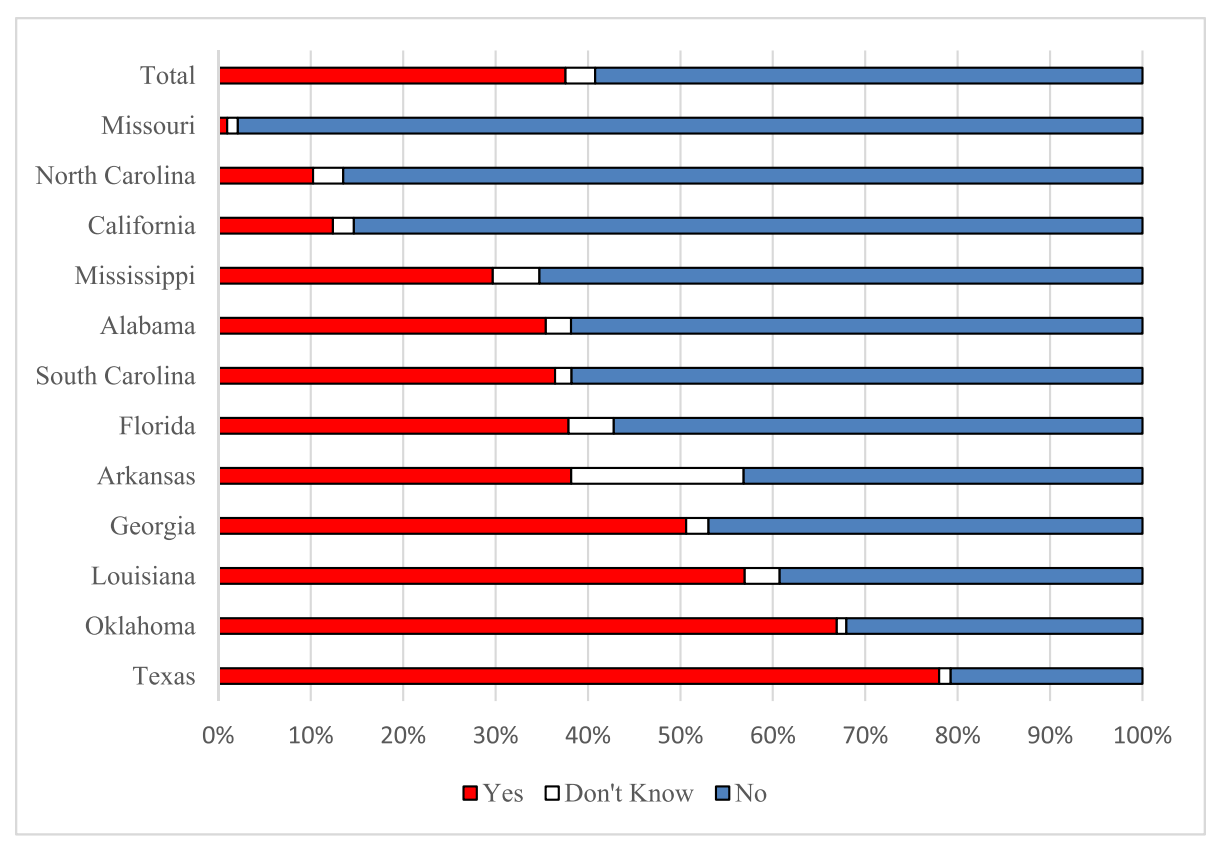

Fig. 7. Percent of landowners reporting wild pig presence on operation. 


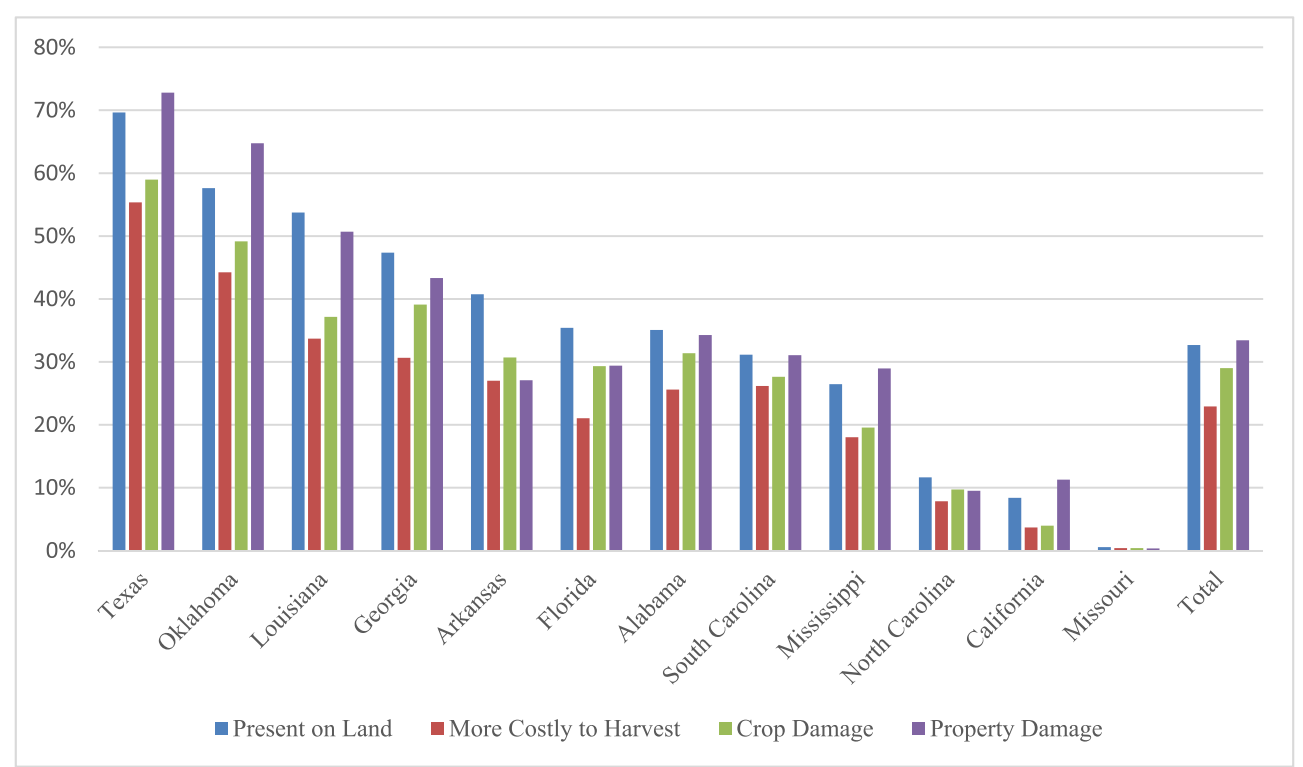

Fig. 8. Percent from each state reporting presence on land and damage.

Table 2

Lost value from feral pigs (1000 US \$).

\begin{tabular}{|c|c|c|c|c|c|c|c|c|c|c|}
\hline State & Hay & Tree Nuts & Melons & Sugarcane & Sweet Potatoes & Cotton & Grapes & Lettuce & Strawberry & Total \\
\hline Alabama & 9834 & 271 & NA & NA & 642 & 2746 & NA & NA & NA & 13,493 \\
\hline Arkansas & 13,272 & 33 & (D) & NA & (D) & 1110 & NA & NA & NA & 14,415 \\
\hline California & 5918 & 2065 & NA & NA & NA & NA & 1909 & - & 1501 & 11,393 \\
\hline Florida & 2472 & 271 & 3062 & 5809 & (D) & 1820 & NA & NA & NA & 13,434 \\
\hline Georgia & 12,263 & 17,873 & 480 & NA & 9 & 17,980 & NA & NA & NA & 48,604 \\
\hline Louisiana & 6335 & 366 & (D) & 1232 & (D) & - & NA & NA & NA & 7932 \\
\hline Mississippi & 1212 & - & (D) & NA & 961 & 261 & NA & NA & NA & 2434 \\
\hline Missouri & 14,922 & NA & - & NA & (D) & - & NA & NA & NA & 14,922 \\
\hline North Carolina & 272 & - & - & NA & 5349 & 319 & NA & NA & NA & 5939 \\
\hline Oklahoma & 15,749 & 990 & (D) & NA & (D) & 1330 & NA & NA & NA & 18,069 \\
\hline South Carolina & 1501 & - & 333 & NA & - & 3494 & NA & NA & NA & 5328 \\
\hline Texas & 78,875 & 17,112 & 8838 & - & (D) & 11,153 & NA & NA & NA & 115,978 \\
\hline Total & 162,626 & 38,979 & 12,714 & 7041 & 6960 & 40,212 & 1909 & - & 1501 & 271,942 \\
\hline
\end{tabular}

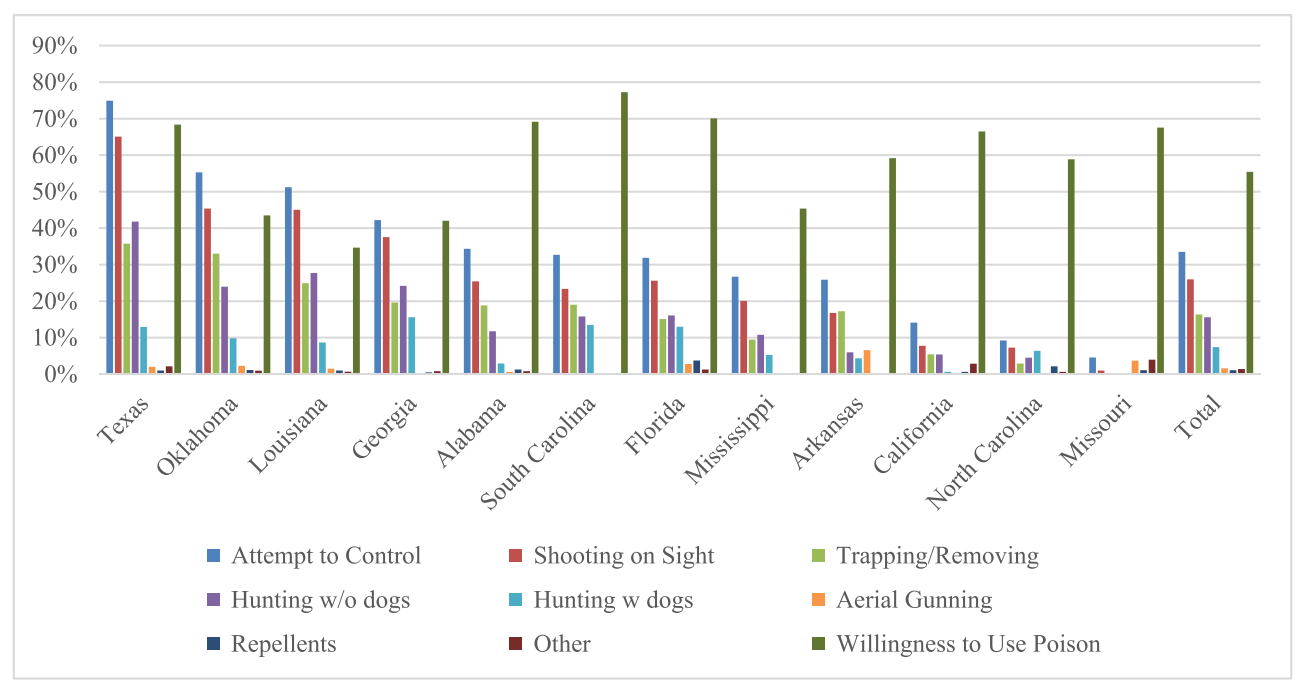

Fig. 9. Percent from each state reporting control and willingness to use poison. 
Table 3

Perceived effectiveness by control method.

\begin{tabular}{cllll}
\hline & $\begin{array}{l}\text { Not } \\
\text { effective }\end{array}$ & $\begin{array}{l}\text { Slightly } \\
\text { effective }\end{array}$ & $\begin{array}{l}\text { Moderately } \\
\text { effective }\end{array}$ & $\begin{array}{l}\text { Very } \\
\text { effective }\end{array}$ \\
\hline Shooting wild pigs & 0.14 & 0.49 & 0.24 & 0.13 \\
on sight & $(0.02)$ & $(0.06)$ & $(0.05)$ & $(0.03)$ \\
Hunting wild pigs & 0.17 & 0.27 & 0.23 & 0.33 \\
with dogs & $(0.05)$ & $(0.07)$ & $(0.06)$ & $(0.13)$ \\
Hunting wild pigs & 0.29 & 0.35 & 0.23 & 0.13 \\
without dogs & $(0.08)$ & $(0.06)$ & $(0.06)$ & $(0.04)$ \\
Aerial Hunting & 0.55 & 0.06 & 0.21 & 0.18 \\
& $(0.19)$ & $(0.03)$ & $(0.11)$ & $(0.10)$ \\
Trapping and & 0.11 & 0.45 & 0.31 & 0.13 \\
removing & $(0.04)$ & $(0.10)$ & $(0.11)$ & $(0.04)$ \\
Repellents & 0.66 & 0.26 & 0.05 & 0.04 \\
& $(0.15)$ & $(0.12)$ & $(0.03)$ & $(0.03)$ \\
\hline
\end{tabular}

\section{Conclusion}

Agricultural crops are a resource providing abundant calories, protein, and essential fatty acids for wildlife, making them particularly vulnerable to damage and consumption (Birnie-Gauvin et al., 2017). Our findings suggest that of 12 the states and the subset of crops included in this study, wild pigs impose the largest burden on agricultural producers in Texas, which can be explained both by the widespread distribution of wild pigs and the importance of crop production in the state. Among the crops surveyed, the highest loss ratio was reported for pecans (Texas $13.46 \%$ and Florida $12.56 \%$ ). During rooting, wild pigs turn up the soil with their noses in search of food, making large depressions in the ground, which interfere with pecan harvest machinery, making harvest less efficient, resulting in loss of yields. Additionally, direct consumption of agricultural crops further reduces yields and profits to agricultural producers (Boyer et al., 2019). Overall, the loss ratio for cotton was lower, ranging from $0 \%$ in Missouri to $3.1 \%$ in Florida. These results are in line with observations from a crop use study in described in Wilber et al. (2019): fruit and nut crops had the greatest crop use per hour of collaring time, followed by cereal, cotton, sugar, oilseed, and grasses.

Our results suggest that wild pig damage to crops is common across crop types and widespread geographically. A total production loss of nearly $\$ 272$ million represents a substantial loss for crop producers, many of which typically operate on very small profit margins. Although such effects are unaccounted for here, a shift in production from high value crops that are attractive to wild pigs to less profitable but less palatable crops has also probably occurred as their range and density has increased. Moreover, $23 \%$ of respondents reported that wild pigs make it more costly for them to harvest their crops. These additional costs or lost revenues are not quantified in this study and are left to further research.

The economic burden of crop damage to crop producers from wild pigs is not limited to the lost production or increase in harvest costs; it also includes the substantial additional cost of control efforts. Many growers reported applying a suite of control methods (34\%), the most common being shooting pigs on sight (26\%), but no method was rated as extremely effective by the majority of the respondents. These results suggest that more research on effective control methods or combinations of control methods would be beneficial. The majority of growers (55\%) appear willing to use a wild pig toxicant on their operation if certain safety criteria were met.

Several limitations of the survey and its analysis should be acknowledged. First, producers may not have accurate perceptions of damage. Such biases may be intentional or unintentional. Also, we are unable to fully characterize all non-response bias that may be present. NASS expended considerable effort to minimize the number of nonresponses, and the response rate was high at about $49 \%$. However, the possibility of bias remains because respondents may have been more likely to incur damage than non-respondents. Furthermore, we use NASS's state-level production value estimates to address potential crop value variability across states, which could occur notably for hay, but we acknowledge that there may also be variation in crop composition within states that is not accounted for. Additionally, missing, incomplete, or meaningless responses at the individual level, which we accounted for by scaling up response weights, are another potential source of bias. Finally, sample sizes for some questions and state-crop combinations are quite small, and in some cases NASS rules prevent disclosure of any information garnered from specific questions.

\section{CRediT authorship contribution statement}

Sophie McKee: Formal analysis, Writing - original draft, Writing review \& editing. Aaron Anderson: Formal analysis, Writing - review \& editing. Keith Carlisle: Writing - review \& editing. Stephanie A. Shwiff: Conceptualization.

Appendix

Table A-1

Wild pigs Presence in County and on Operation in the Last Three Years.

\begin{tabular}{|c|c|c|c|c|c|c|}
\hline & \multicolumn{3}{|c|}{ In county } & \multicolumn{3}{|c|}{ On operation } \\
\hline & Yes & don't know & No & Yes & don't know & No \\
\hline Alabama & $\begin{array}{l}0.61 \\
(0.05)\end{array}$ & $\begin{array}{l}0.09 \\
(0.02)\end{array}$ & $\begin{array}{l}0.29 \\
(0.05)\end{array}$ & $\begin{array}{l}0.35 \\
(0.05)\end{array}$ & $\begin{array}{l}0.03 \\
(0.01)\end{array}$ & $\begin{array}{l}0.62 \\
(0.05)\end{array}$ \\
\hline Arkansas & $\begin{array}{l}0.61 \\
(0.10)\end{array}$ & $\begin{array}{l}0.09 \\
(0.03)\end{array}$ & $\begin{array}{l}0.30 \\
(0.10)\end{array}$ & $\begin{array}{l}0.38 \\
(0.08)\end{array}$ & $\begin{array}{l}0.19 \\
(0.11)\end{array}$ & $\begin{array}{l}0.43 \\
(0.08)\end{array}$ \\
\hline California & $\begin{array}{l}0.31 \\
(0.02)\end{array}$ & $\begin{array}{l}0.18 \\
(0.02)\end{array}$ & $\begin{array}{l}0.51 \\
(0.03)\end{array}$ & $\begin{array}{l}0.12 \\
(0.02)\end{array}$ & $\begin{array}{l}0.02 \\
(0.01)\end{array}$ & $\begin{array}{l}0.85 \\
(0.02)\end{array}$ \\
\hline Florida & $\begin{array}{l}0.62 \\
(0.04)\end{array}$ & $\begin{array}{l}0.19 \\
(0.04)\end{array}$ & $\begin{array}{l}0.19 \\
(0.03)\end{array}$ & $\begin{array}{l}0.38 \\
(0.04)\end{array}$ & $\begin{array}{l}0.05 \\
(0.03)\end{array}$ & $\begin{array}{l}0.57 \\
(0.04)\end{array}$ \\
\hline Georgia & $\begin{array}{l}0.78 \\
(0.03)\end{array}$ & $\begin{array}{l}0.06 \\
(0.02)\end{array}$ & $\begin{array}{l}0.16 \\
(0.03)\end{array}$ & $\begin{array}{l}0.51 \\
(0.04)\end{array}$ & $\begin{array}{l}0.02 \\
(0.01)\end{array}$ & $\begin{array}{l}0.47 \\
(0.04)\end{array}$ \\
\hline Louisiana & $\begin{array}{l}0.73 \\
(0.05)\end{array}$ & $\begin{array}{l}0.10 \\
(0.03)\end{array}$ & $\begin{array}{l}0.17 \\
(0.04)\end{array}$ & $\begin{array}{l}0.57 \\
(0.06)\end{array}$ & $\begin{array}{l}0.04 \\
(0.02)\end{array}$ & $\begin{array}{l}0.39 \\
(0.05)\end{array}$ \\
\hline Mississippi & $\begin{array}{l}0.70 \\
(0.05)\end{array}$ & $\begin{array}{l}0.10 \\
(0.03)\end{array}$ & $\begin{array}{l}0.20 \\
(0.04)\end{array}$ & $\begin{array}{l}0.30 \\
(0.04)\end{array}$ & $\begin{array}{l}0.05 \\
(0.02)\end{array}$ & $\begin{array}{l}0.65 \\
(0.05)\end{array}$ \\
\hline Missouri & $\begin{array}{l}0.08 \\
(0.03)\end{array}$ & $\begin{array}{l}0.29 \\
(0.06)\end{array}$ & $\begin{array}{l}0.63 \\
(0.06)\end{array}$ & $\begin{array}{l}0.01 \\
(0.00)\end{array}$ & $\begin{array}{l}0.01 \\
(0.01)\end{array}$ & $\begin{array}{l}0.98 \\
(0.01)\end{array}$ \\
\hline
\end{tabular}


Table A-1 (continued)

\begin{tabular}{|c|c|c|c|c|c|c|}
\hline & \multicolumn{3}{|c|}{ In county } & \multicolumn{3}{|c|}{ On operation } \\
\hline & Yes & don't know & No & Yes & don't know & No \\
\hline North Carolina & $\begin{array}{l}0.36 \\
(0.05)\end{array}$ & $\begin{array}{l}0.16 \\
(0.03)\end{array}$ & $\begin{array}{l}0.48 \\
(0.05)\end{array}$ & $\begin{array}{l}0.10 \\
(0.03)\end{array}$ & $\begin{array}{l}0.03 \\
(0.01)\end{array}$ & $\begin{array}{l}0.86 \\
(0.03)\end{array}$ \\
\hline Oklahoma & $\begin{array}{l}0.85 \\
(0.03)\end{array}$ & $\begin{array}{l}0.08 \\
(0.02)\end{array}$ & $\begin{array}{l}0.07 \\
(0.02)\end{array}$ & $\begin{array}{l}0.67 \\
(0.04)\end{array}$ & $\begin{array}{l}0.01 \\
(0.01)\end{array}$ & $\begin{array}{l}0.32 \\
(0.04)\end{array}$ \\
\hline South Carolina & $\begin{array}{l}0.67 \\
(0.05)\end{array}$ & $\begin{array}{l}0.11 \\
(0.03)\end{array}$ & $\begin{array}{l}0.22 \\
(0.04)\end{array}$ & $\begin{array}{l}0.36 \\
(0.05)\end{array}$ & $\begin{array}{l}0.02 \\
(0.01)\end{array}$ & $\begin{array}{l}0.62 \\
(0.05)\end{array}$ \\
\hline Texas & $\begin{array}{l}0.91 \\
(0.02)\end{array}$ & $\begin{array}{l}0.02 \\
(0.01)\end{array}$ & $\begin{array}{l}0.07 \\
(0.02)\end{array}$ & $\begin{array}{l}0.78 \\
(0.03)\end{array}$ & $\begin{array}{l}0.01 \\
(0.01)\end{array}$ & $\begin{array}{l}0.21 \\
(0.03)\end{array}$ \\
\hline Total & $\begin{array}{l}0.59 \\
(0.01)\end{array}$ & $\begin{array}{l}0.12 \\
(0.01)\end{array}$ & $\begin{array}{l}0.29 \\
(0.01)\end{array}$ & $\begin{array}{l}0.38 \\
(0.01)\end{array}$ & $\begin{array}{l}0.03 \\
(0.01)\end{array}$ & $\begin{array}{l}0.59 \\
(0.01)\end{array}$ \\
\hline
\end{tabular}

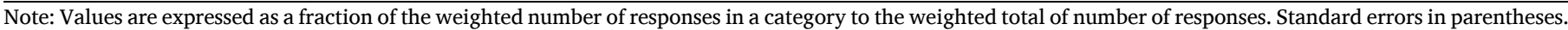

Table A-2

Fraction from Each State Reporting Presence on Land and Damage.

\begin{tabular}{|c|c|c|c|c|}
\hline & Present on land & More costly to harvest & Crop damage & Property damage \\
\hline Alabama & $\begin{array}{l}0.35 \\
(0.05)\end{array}$ & $\begin{array}{l}0.26 \\
(0.05)\end{array}$ & $\begin{array}{l}0.31 \\
(0.05)\end{array}$ & $\begin{array}{l}0.34 \\
(0.05)\end{array}$ \\
\hline Arkansas & $\begin{array}{l}0.41 \\
(0.08)\end{array}$ & $\begin{array}{l}0.27 \\
(0.08)\end{array}$ & $\begin{array}{l}0.31 \\
(0.08)\end{array}$ & $\begin{array}{l}0.27 \\
(0.07)\end{array}$ \\
\hline California & $\begin{array}{l}0.08 \\
(0.02)\end{array}$ & $\begin{array}{l}0.04 \\
(0.01)\end{array}$ & $\begin{array}{l}0.04 \\
(0.01)\end{array}$ & $\begin{array}{l}0.11 \\
(0.02)\end{array}$ \\
\hline Florida & $\begin{array}{l}0.35 \\
(0.05)\end{array}$ & $\begin{array}{l}0.21 \\
(0.04)\end{array}$ & $\begin{array}{l}0.29 \\
(0.05)\end{array}$ & $\begin{array}{l}0.29 \\
(0.04)\end{array}$ \\
\hline Georgia & $\begin{array}{l}0.47 \\
(0.04)\end{array}$ & $\begin{array}{l}0.31 \\
(0.04)\end{array}$ & $\begin{array}{l}0.39 \\
(0.04)\end{array}$ & $\begin{array}{l}0.43 \\
(0.04)\end{array}$ \\
\hline Louisiana & $\begin{array}{l}0.54 \\
(0.07)\end{array}$ & $\begin{array}{l}0.34 \\
(0.06)\end{array}$ & $\begin{array}{l}0.37 \\
(0.06)\end{array}$ & $\begin{array}{l}0.51 \\
(0.06)\end{array}$ \\
\hline Mississippi & $\begin{array}{l}0.26 \\
(0.05)\end{array}$ & $\begin{array}{l}0.18 \\
(0.04)\end{array}$ & $\begin{array}{l}0.20 \\
(0.05)\end{array}$ & $\begin{array}{l}0.29 \\
(0.05)\end{array}$ \\
\hline Missouri & $\begin{array}{l}0.01 \\
(0.00)\end{array}$ & $\begin{array}{l}0.00 \\
(0.00)\end{array}$ & $\begin{array}{l}0.00 \\
(0.00)\end{array}$ & $\begin{array}{l}0.00 \\
(0.00)\end{array}$ \\
\hline North Carolina & $\begin{array}{l}0.12 \\
(0.04)\end{array}$ & $\begin{array}{l}0.08 \\
(0.04)\end{array}$ & $\begin{array}{l}0.10 \\
(0.04)\end{array}$ & $\begin{array}{l}0.10 \\
(0.03)\end{array}$ \\
\hline Oklahoma & $\begin{array}{l}0.58 \\
(0.05)\end{array}$ & $\begin{array}{l}0.44 \\
(0.05)\end{array}$ & $\begin{array}{l}0.49 \\
(0.05)\end{array}$ & $\begin{array}{l}0.65 \\
(0.04)\end{array}$ \\
\hline South Carolina & $\begin{array}{l}0.31 \\
(0.05)\end{array}$ & $\begin{array}{l}0.26 \\
(0.05)\end{array}$ & $\begin{array}{l}0.28 \\
(0.05)\end{array}$ & $\begin{array}{l}0.31 \\
(0.05)\end{array}$ \\
\hline Texas & $\begin{array}{l}0.70 \\
(0.04)\end{array}$ & $\begin{array}{l}0.55 \\
(0.04)\end{array}$ & $\begin{array}{l}0.59 \\
(0.04)\end{array}$ & $\begin{array}{l}0.73 \\
(0.03)\end{array}$ \\
\hline Total & $\begin{array}{l}0.33 \\
(0.01)\end{array}$ & $\begin{array}{l}0.23 \\
(0.01)\end{array}$ & $\begin{array}{l}0.29 \\
(0.01)\end{array}$ & $\begin{array}{l}0.33 \\
(0.01)\end{array}$ \\
\hline
\end{tabular}

Note: Values are expressed as a fraction of the weighted number of responses in a category to the weighted total of number of responses. Standard errors in parentheses.

Table A-3

Number of Usable Observations.

\begin{tabular}{|c|c|c|c|c|c|c|c|c|c|}
\hline State & Hay, haylage & Tree nuts & Melons & Sugarcane & Sweet potatoes & Cotton & Grapes & Lettuce & Strawberry \\
\hline Alabama & 43 & 24 & 5 & 0 & 4 & 56 & NA & NA & NA \\
\hline Arkansas & 40 & 10 & 3 & 0 & 1 & 19 & NA & NA & NA \\
\hline California & 92 & 346 & NA & NA & NA & NA & 380 & 7 & 17 \\
\hline Florida & 47 & 25 & 7 & 4 & 1 & 14 & NA & NA & NA \\
\hline Georgia & 61 & 61 & 7 & 0 & 4 & 71 & NA & NA & NA \\
\hline Louisiana & 27 & 19 & 3 & 16 & 2 & 8 & NA & NA & NA \\
\hline Mississippi & 56 & 7 & 1 & 0 & 6 & 20 & NA & NA & NA \\
\hline Missouri & 70 & 2 & 4 & 0 & 1 & 20 & NA & NA & NA \\
\hline North Carolina & 35 & 11 & 4 & 0 & 37 & 31 & NA & NA & NA \\
\hline Oklahoma & 118 & 20 & 3 & 1 & 1 & 34 & NA & NA & NA \\
\hline South Carolina & 58 & 13 & 8 & 4 & 3 & 27 & NA & NA & NA \\
\hline Texas & 108 & 72 & 13 & 4 & 1 & 54 & NA & NA & NA \\
\hline
\end{tabular}


Table A-4

Fraction from Each State Reporting Control and Willingness to Use Poison ( ).Anderson et al., 2016

\begin{tabular}{|c|c|c|c|c|c|c|c|c|c|c|c|}
\hline State & $\begin{array}{l}\text { Attempt to } \\
\text { control }\end{array}$ & $\begin{array}{l}\text { Shooting on } \\
\text { sight }\end{array}$ & $\begin{array}{l}\text { Hunting } \\
\text { with dogs }\end{array}$ & $\begin{array}{l}\text { Hunting } \\
\text { without dogs }\end{array}$ & $\begin{array}{l}\text { Aerial } \\
\text { gunning }\end{array}$ & $\begin{array}{l}\text { Trapping } \\
\text { removing }\end{array}$ & Repellents & Other & $\begin{array}{l}\text { Electric } \\
\text { fencing }\end{array}$ & $\begin{array}{l}\text { Non- electric } \\
\text { fencing }\end{array}$ & $\begin{array}{l}\text { Willing to } \\
\text { use poison }\end{array}$ \\
\hline $\mathrm{AL}$ & $\begin{array}{l}0.34 \\
(0.05)\end{array}$ & $\begin{array}{l}0.25 \\
(0.04)\end{array}$ & $\begin{array}{l}0.03 \\
(0.01)\end{array}$ & $\begin{array}{l}0.12 \\
(0.03)\end{array}$ & $\begin{array}{l}0.02 \\
(0.01)\end{array}$ & $\begin{array}{l}0.19 \\
(0.81)\end{array}$ & $\begin{array}{l}0.01 \\
(0.99)\end{array}$ & $\begin{array}{l}0.02 \\
(0.98)\end{array}$ & $\begin{array}{l}0.09 \\
(0.91)\end{array}$ & $\begin{array}{l}0.03 \\
(0.97)\end{array}$ & $\begin{array}{l}0.68 \\
(0.05)\end{array}$ \\
\hline AR & $\begin{array}{l}0.26 \\
(0.07)\end{array}$ & $\begin{array}{l}0.17 \\
(0.05)\end{array}$ & $\begin{array}{l}0.04 \\
(0.03)\end{array}$ & $\begin{array}{l}0.06 \\
(0.03)\end{array}$ & $\begin{array}{l}0.02 \\
(0.01)\end{array}$ & $\begin{array}{l}0.17 \\
(0.06)\end{array}$ & $\begin{array}{l}0.01 \\
(0.01)\end{array}$ & $\begin{array}{l}0.01 \\
(0.00)\end{array}$ & $\begin{array}{l}0.11 \\
(0.06)\end{array}$ & $\begin{array}{l}0.09 \\
(0.06)\end{array}$ & $\begin{array}{l}0.43 \\
(0.08)\end{array}$ \\
\hline $\mathrm{CA}$ & $\begin{array}{l}0.14 \\
(0.02)\end{array}$ & $\begin{array}{l}0.08 \\
(0.02)\end{array}$ & $\begin{array}{l}0.01 \\
(0.00)\end{array}$ & $\begin{array}{l}0.05 \\
(0.01)\end{array}$ & $\begin{array}{l}0.02 \\
(0.01)\end{array}$ & $\begin{array}{l}0.05 \\
(0.02)\end{array}$ & $\begin{array}{l}0.01 \\
(0.01)\end{array}$ & $\begin{array}{l}0.01 \\
(0.00)\end{array}$ & $\begin{array}{l}0.01 \\
(0.01)\end{array}$ & $\begin{array}{l}0.07 \\
(0.02)\end{array}$ & $\begin{array}{l}0.35 \\
(0.03)\end{array}$ \\
\hline FL & $\begin{array}{l}0.32 \\
(0.04)\end{array}$ & $\begin{array}{l}0.26 \\
(0.03)\end{array}$ & $\begin{array}{l}0.13 \\
(0.03)\end{array}$ & $\begin{array}{l}0.16 \\
(0.03)\end{array}$ & $\begin{array}{l}0.00 \\
-\end{array}$ & $\begin{array}{l}0.15 \\
(0.03)\end{array}$ & $\begin{array}{l}0.00 \\
(0.00)\end{array}$ & $\begin{array}{l}0.01 \\
(0.00)\end{array}$ & $\begin{array}{l}0.03 \\
(0.02)\end{array}$ & $\begin{array}{l}0.04 \\
(0.01)\end{array}$ & $\begin{array}{l}0.42 \\
(0.04)\end{array}$ \\
\hline GA & $\begin{array}{l}0.42 \\
(0.04)\end{array}$ & $\begin{array}{l}0.38 \\
(0.04)\end{array}$ & $\begin{array}{l}0.16 \\
(0.03)\end{array}$ & $\begin{array}{l}0.24 \\
(0.03)\end{array}$ & $\begin{array}{l}0.01 \\
(0.00)\end{array}$ & $\begin{array}{l}0.20 \\
(0.03)\end{array}$ & $\begin{array}{l}0.01 \\
(0.01)\end{array}$ & $\begin{array}{l}0.01 \\
(0.00)\end{array}$ & $\begin{array}{l}0.04 \\
(0.02)\end{array}$ & $\begin{array}{l}0.02 \\
(0.01)\end{array}$ & $\begin{array}{l}0.69 \\
(0.04)\end{array}$ \\
\hline LA & $\begin{array}{l}0.51 \\
(0.06)\end{array}$ & $\begin{array}{l}0.45 \\
(0.06)\end{array}$ & $\begin{array}{l}0.09 \\
(0.03)\end{array}$ & $\begin{array}{l}0.28 \\
(0.06)\end{array}$ & $\begin{array}{l}0.00 \\
(0.00)\end{array}$ & $\begin{array}{l}0.25 \\
(0.05)\end{array}$ & $\begin{array}{l}0.00 \\
(0.00)\end{array}$ & $\begin{array}{l}0.00 \\
(0.01)\end{array}$ & $\begin{array}{l}0.04 \\
(0.01)\end{array}$ & $\begin{array}{l}0.02 \\
(0.01)\end{array}$ & $\begin{array}{l}0.77 \\
(0.04)\end{array}$ \\
\hline MS & $\begin{array}{l}0.27 \\
(0.04)\end{array}$ & $\begin{array}{l}0.20 \\
(0.04)\end{array}$ & $\begin{array}{l}0.05 \\
(0.03)\end{array}$ & $\begin{array}{l}0.11 \\
(0.03)\end{array}$ & $\begin{array}{l}0.03 \\
(0.02)\end{array}$ & $\begin{array}{l}0.09 \\
(0.03)\end{array}$ & $\begin{array}{l}0.04 \\
(0.02)\end{array}$ & $\begin{array}{l}0.01 \\
(0.00)\end{array}$ & $\begin{array}{l}0.02 \\
(0.01)\end{array}$ & $\begin{array}{l}0.03 \\
(0.01)\end{array}$ & $\begin{array}{l}0.70 \\
(0.04)\end{array}$ \\
\hline MO & $\begin{array}{l}0.05 \\
(0.03)\end{array}$ & $\begin{array}{l}0.01 \\
(0.01)\end{array}$ & $\begin{array}{l}0.00 \\
-\end{array}$ & $\begin{array}{l}0.00 \\
(0.00)\end{array}$ & $\begin{array}{l}0.00 \\
(0.00)\end{array}$ & $\begin{array}{l}0.00 \\
-\end{array}$ & $\begin{array}{l}0.00 \\
-\end{array}$ & $\begin{array}{l}0.00 \\
-\end{array}$ & $\begin{array}{l}0.03 \\
(0.02)\end{array}$ & $\begin{array}{l}0.02 \\
(0.02)\end{array}$ & $\begin{array}{l}0.45 \\
(0.06)\end{array}$ \\
\hline NC & $\begin{array}{l}0.09 \\
(0.03)\end{array}$ & $\begin{array}{l}0.07 \\
(0.03)\end{array}$ & $\begin{array}{l}0.06 \\
(0.03)\end{array}$ & $\begin{array}{l}0.05 \\
(0.02)\end{array}$ & $\begin{array}{l}0.07 \\
(0.02)\end{array}$ & $\begin{array}{l}0.03 \\
(0.02)\end{array}$ & $\begin{array}{l}0.00 \\
(0.00)\end{array}$ & $\begin{array}{l}0.00 \\
(0.02)\end{array}$ & $\begin{array}{l}0.00 \\
(0.00)\end{array}$ & $\begin{array}{l}0.00 \\
(0.00)\end{array}$ & $\begin{array}{l}0.59 \\
(0.05)\end{array}$ \\
\hline OK & $\begin{array}{l}0.55 \\
(0.05)\end{array}$ & $\begin{array}{l}0.45 \\
(0.04)\end{array}$ & $\begin{array}{l}0.10 \\
(0.02)\end{array}$ & $\begin{array}{l}0.24 \\
(0.04)\end{array}$ & $\begin{array}{l}- \\
-\end{array}$ & $\begin{array}{l}0.33 \\
(0.04)\end{array}$ & $\begin{array}{l}0.01 \\
(0.00)\end{array}$ & $\begin{array}{l}0.03 \\
(0.02)\end{array}$ & $\begin{array}{l}0.05 \\
(0.02)\end{array}$ & $\begin{array}{l}0.03 \\
(0.02)\end{array}$ & $\begin{array}{l}0.67 \\
(0.04)\end{array}$ \\
\hline SC & $\begin{array}{l}0.33 \\
(0.06)\end{array}$ & $\begin{array}{l}0.23 \\
(0.05)\end{array}$ & $\begin{array}{l}0.13 \\
(0.05)\end{array}$ & $\begin{array}{l}0.16 \\
(0.05)\end{array}$ & $\begin{array}{l}0.00 \\
(0.00)\end{array}$ & $\begin{array}{l}0.19 \\
(0.05)\end{array}$ & $\begin{array}{l}0.02 \\
(0.01)\end{array}$ & $\begin{array}{l}0.01 \\
(0.01)\end{array}$ & $\begin{array}{l}0.07 \\
(0.03)\end{array}$ & $\begin{array}{l}0.04 \\
(0.03)\end{array}$ & $\begin{array}{l}0.59 \\
(0.05)\end{array}$ \\
\hline TX & $\begin{array}{l}0.75 \\
(0.03)\end{array}$ & $\begin{array}{l}0.65 \\
(0.03)\end{array}$ & $\begin{array}{l}0.13 \\
(0.02)\end{array}$ & $\begin{array}{l}0.42 \\
(0.04)\end{array}$ & $\begin{array}{l}0.04 \\
(0.01)\end{array}$ & $\begin{array}{l}0.36 \\
(0.03)\end{array}$ & $\begin{array}{l}0.01 \\
(0.01)\end{array}$ & $\begin{array}{l}0.04 \\
(0.01)\end{array}$ & $\begin{array}{l}0.11 \\
(0.02)\end{array}$ & $\begin{array}{l}0.17 \\
(0.03)\end{array}$ & $\begin{array}{l}0.68 \\
(0.03)\end{array}$ \\
\hline Total & $\begin{array}{l}0.34 \\
(0.01)\end{array}$ & $\begin{array}{l}0.26 \\
(0.01)\end{array}$ & $\begin{array}{l}0.07 \\
(0.01)\end{array}$ & $\begin{array}{l}0.16 \\
(0.01)\end{array}$ & $\begin{array}{l}0.02 \\
(0.00)\end{array}$ & $\begin{array}{l}0.16 \\
(0.01)\end{array}$ & $\begin{array}{l}0.01 \\
(0.00)\end{array}$ & $\begin{array}{l}0.01 \\
(0.00)\end{array}$ & $\begin{array}{l}0.04 \\
(0.01)\end{array}$ & $\begin{array}{l}0.06 \\
(0.01)\end{array}$ & $\begin{array}{l}0.55 \\
(0.01)\end{array}$ \\
\hline
\end{tabular}

\section{References}

Anderson, A., Slootmaker, C., Harper, E., Holderieath, J., Shwiff, S.A., 2016. Economic estimates of feral swine damage and control in 11 US states. Crop Protect. 89, 89-94.

Anderson, A., Slootmaker, C., Harper, E., Miller, R.S., Shwiff, S.A., 2019. Predation and disease-related economic impacts of wild pigs on livestock producers in 13 states. Crop Protect. 121, 121-126.

Birnie-Gauvin, K., Peiman, K.S., Raubenheimer, D., Cooke, S.J., 2017. Nutritional physiology and ecology of wildlife in a changing world. Conserv. Physiol. 5 (1) cox030.

Boyer, K.S., Fairbanks, W.S., Rohla, C., Webb, S.L., 2019. Surficial Soil Damage by Wild Pigs (Sus scrofa) Decreases Pecan Harvest Efficiency. Crop Protection, 104992.

Brook, R.K., van Beest, F.M., 2014. Feral wild boar distribution and perceptions of risk on the central Canadian prairies. Wildl. Soc. Bull. 38 (3), 486-494.

Conover, M., 2002. Resolving Human-Wildlife Conflicts: the Science of Wildlife Damage Management. CRC Press, Boca Raton.

Corn, J.L., Jordan, T.R., 2017. Development of the national feral swine map, 1982-2016. Wildl. Soc. Bull. 41 (4), 758-763.

Harper, E.E., Miller, C.A., Vaske, J.J., Mengak, M.T., Bruno, S., 2016. Stakeholder attitudes and beliefs toward wild pigs in Georgia and Illinois. Wildl. Soc. Bull. 40 (2), 269-273.

Johnson-Nistler, C.M., Knight, J.E., Cash, S.D., 2005. Considerations related to Richardson's ground Squirrel control in Montana. Agron. J. 97 (5), 1460-1464.

Keiter, D.A., Mayer, J.J., Beasley, J.C., 2016. What is in a "common" name? A call for consistent terminology for nonnative Sus scrofa. Wildl. Soc. Bull. 40 (2), 384-387.

Kott, P.S., Amrhein, J.F., Hicks, S.D., 1998. Sampling and estimation from multiple list frames. Surv. Methodol. 24, 3-10.
Lewis, J.S., Farnsworth, M.L., Burdett, C.L., Theobald, D.M., Gray, M., Miller, R.S., 2017. Biotic and abiotic factors predicting the global distribution and population density of an invasive large mammal. Sci. Rep. 7, 44152.

Lewis, J.S., Corn, J.L., Mayer, J.J., Jordan, T.R., Farnsworth, M.L., Burdett, C.L., et al., 2019. Historical, current, and potential population size estimates of invasive wild pigs (Sus scrofa) in the United States. Biol. Invasions 21 (7), 2373-2384.

McClure, M.L., Burdett, C.L., Farnsworth, M.L., Lutman, M.W., Theobald, D.M., Riggs, P. D., Miller, R.S., 2015. Modeling and mapping the probability of occurrence of invasive wild pigs across the contiguous United States. PloS One 10 (8), e0133771.

Pepin, K.M., Wolfson, D.W., Miller, R.S., Tabak, M.A., Snow, N.P., VerCauteren, K.C., Davis, A.J., 2019. Accounting for heterogeneous invasion rates reveals management impacts on the spatial expansion of an invasive species. Ecosphere 10 (3), e02657.

Pimentel, David, 2007. Environmental and economic costs of vertebrate species invasions into the United States. In: Managing Vertebrate Invasive Species, 38.

Seward, N.W., VerCauteren, K.C., Witmer, G.W., Engeman, R.M., 2004. Feral swine impacts on agriculture and the environment. Sheep Goat Res. J. 12.

Snow, N.P., Jarzyna, M.A., VerCauteren, K.C., 2017. Interpreting and predicting the spread of invasive wild pigs. J. Appl. Ecol. 54 (6), 2022-2032.

Tzilkowski, W.M., Brittingham, M.C., Lovallo, M.J., 2002. Wildlife damage to corn in Pennsylvania: Farmer and on-the-ground estimates. J. Wildl. Manag. 66 (3), 678-682.

Wilber, M.Q., Chinn, S.M., Beasley, J.C., Pepin, K.M., 2019. Selection for agricultural crops predicts space use of a rapidly expanding invasive species in North America. In: Integrative and Comparative Biology, 59. E247-E247.

Wywialowski, A.P., 1994. Agricultural producers' perceptions of wildlife-caused losses. Wildl. Soc. Bull. 22 (3), 370-382. 